\title{
Quercetin Inhibits Chronic Stress-Induced Myocardial Infarction in Rats
}

\author{
La Quercetina Inhibe el Infarto al Miocardio Inducido por Estrés Crónico en Ratas
}

\author{
Ismaeel Bin-Jaliah
}

BIN-JALIAH, I. Quercetin inhibits chronic stress-induced myocardial infarction in rats. Int. J. Morphol., 35(4):1363-1369, 2017.

\begin{abstract}
SUMMARY: We recently reported that chronic unpredictable stress (CUS) induced left ventricular dysfunction (LVD) in rats, which was inhibited by the cardioprotective agent quercetin. Based on these findings and because majority of patients with myocardial infarction (MI) can develop LVD and heart failure, we sought to produce an animal model of MI and LVD in rats and use this model to test the hypothesis that quercetin is able to prevent the potential MI induction by CUS. Rats were exposed to CUS using a variety of stressors in the presence and absence of quercetin $(50 \mathrm{mg} / \mathrm{kg}$ body weight/day) for 21 days. Blood pressure and electrocardiogram (ECG) were recorded in all rat groups together with the examination of left ventricle (LV) tissue homogenates and sections to confirm the production of the animal model. We further extend on our recent findings on the role of apoptosis in the pathology of LVD and eventually MI. Blood pressure measurements and ECG recording confirmed the development of systemic hypertension and MI in the model group of rats exposed to CUS. In addition, histological staining confirmed that LV damages occurred in the same group. Furthermore, the proapoptotic gene Bax and the inflammatory biomarkers, TNF- $\alpha$ and IL-6 were augmented in LV homogenates by CUS. Simultaneous quercetin treatment lowered blood pressure and substantially prevented MI since it blocked the elevation of ST segment on the ECG and maintained a normal ECG reading. Quercetin suppressed the expression of Bax RNA messages, and significantly ( $p<0.05$ ) blocked CUS-induced TNF- $\alpha$ and IL-6 upregulation. Thus, CUS induced MI in rats associated with augmentation of tissue injury biomarkers were prevented by quercetin, which further endorses our recent findings of a potential therapeutic role for quercetin in CUS induced cardiac dysfunction.
\end{abstract}

KEY WORDS: Chronic stress; Myocardial infarction; ECG; Rat model; Quercetin; Inflammatory biomarkers.

\section{INTRODUCTION}

Chronic stress occurs in both humans and experimental animal models after a prolonged exposure to stressors that could lead to biochemical, physiological and behavioural changes, which affect many systems including the cardiovascular system, immune, endocrine and central nervous systems (Rozanski et al., 1999). Indeed, a metaanalysis study on the effect of work stress on the increased risk of coronary heart disease (CHD) among Scandinavians reported a $50 \%$ increase risk of CHD among employees with work stress (Kivimäki et al., 2006). CHD also increased in people who experienced stressful childhood (Dong et al., 2004), and the risk of myocardial infarction (MI) has increased in hopelessness middle-age men, depression, and in parents who lost a child (Everson et al., 1996; Pratt et al., 1996; Li et al., 2002). However, treating psychological factors such as depression and chronic life stress reduced coronary artery disease (Rozanski et al., 2005). Interestingly, animal study that reported a $27 \%$ death from cardiac arrest in serotonin receptor knockout mice exposing to chronic stress (Carnevali et al., 2012) supported the human data.

Quercetin is a flavonoid antioxidant found in fruits, vegetables and grains, and is the most abundant flavonol in the human diet (Burda \& Oleszek, 2001). Quercetin has been widely known to have a potent cardiovascular protective and therapeutic effect via scavenging reactive oxygen species (Burda \& Oleszek; Park et al., 2003), antihypertensive effects (Duarte et al., 2001), antiinflammatory (Rogerio et al., 2007), preventing apoptosis and promoting cell survival (Choi et al., 2005), and caused inhibition of platelet aggregation and thrombus formation (Hubbard et al., 2004).

MI, commonly known as a heart attack is caused by the death of cardiac muscle (cardiomyocytes) due to ischemic coronary artery disease (Nabel \& Braunwald, 2012). Men- 
tal stress, depression and anxiety are recognized among many risk factors that trigger MI, which include the traditional risk factors such as hypertension, hyperlipidemia, diabetes, smoking, and sedentary lifestyle (Valensi et al., 2011; Mehta et al., 2015). The ECG is the most important tool in the initial evaluation of patients suspect having acute coronary syndrome, such as MI, and ST segment elevation is a confirmed diagnosis of MI ( Task Force on the management of ST-segment elevation acute myocardial infarction of the European Society of Cardiology et al., 2012). Severe emotional and / or physical stress in humans caused damage to the left ventricle and account for about $2 \%$ of MI cases, mostly in women (Roshanzamir \& Showkathali, 2013). In addition, majority of patients with MI developed LVD (Mateus et al., 2005). However, very little is known about the effect of chronic stress on the incidence of MI in animal models, and the beneficial effect of quercetin on MI induced in rats was not investigated before. Therefore, we generated a rat model of CUS-induced both MI and LVD and tested the hypothesis that quercetin can block MI development in this model.

\section{MATERIAL AND METHOD}

Animals. Experiments were performed with the approval of the Research Ethics Committee at the College of Medicine, King Khalid University, Abha, Saudi Arabia, and all procedures were performed according to the Guide for the Care and Use of Laboratory Animals published by the US National Institutes of Health (NIH publication No. 85-23, revised 1996). Male Wistar rats of 8 weeks of age and weighing $230 \pm 10 \mathrm{~g}$ were used for the experiments and obtained and maintained at the animal house of the College of Medicine, where they fed standard rat pellets and allowed free access to water. The housing conditions were a controlled ambient temperature of $25 \pm 2{ }^{\circ} \mathrm{C}$ and $50 \pm 10$ $\%$ relative humidity, with 12 -h light/12-h dark cycles.

Experimental design. After a one week adaptation period, rats were randomly assigned to 4 groups ( $\mathrm{n}=6$ each) as follows: 1. Control group: received normal saline. 2. Quercetin treated group (Control+Qur): received Qur (50 $\mathrm{mg} / \mathrm{kg}$ ). 3. Chronic unpredictable stress (CUS) group: a model group and were exposed to CUS protocol, as detailed below and received normal saline. 4. CUS + Qur treated group: were exposed to CUS with a concomitant daily dose of Qur $(50 \mathrm{mg} / \mathrm{kg})$. All treatments were administered as 1 $\mathrm{ml}$, i.p. for three consecutive weeks on daily basis. QUR was always prepared fresh, daily, by dissolving in normal saline to the final concentration used in the experimental procedure.
Chronic unpredictable stress (CUS) protocol. According to the method established previously (Harro, 1999), a set of chronic unpredictable mild stressors were used to induced depression in rats that lasted for 3 weeks.

Cardiac hemodynamic measurements. Eight hours after the last dose on day 21, cardiac hemodynamic measurements were assessed in each group. In brief, rats were anaesthetized with $1 \%$ solution of sodium pentobarbital $(50 \mathrm{mg} / \mathrm{kg}$; i.p.) and placed on a heating pad to maintain body temperature. After performing tracheal intubation and ventilation, the right carotid artery was cannulated using a polyethylene pressure catheter (SPR-320 pressure catheter, AD Instruments, Sydney, Australia) prefilled with heparin $(50 \mathrm{U} / \mathrm{mL})$ and connected to a pre-calibrated bridge amplifier. Subsequently, after stabilization of the cardiovascular parameters, the systolic blood pressure (SBP), diastolic blood pressure (DBP), and mean arterial blood pressure (MAP) were measured. Also, ECG was recorded using 3 touch electrodes connected to an animal bio-amplifier (FE136 Animal Bio Amp, AD Instruments, Australia) attached to the skin of the animals in the standard 3 positions and heart rate (HR) was recorded. All data was recorded and analyzed with a PowerLab data acquisition system (ML780 PowerLab/ 8channels, AD Instruments Ltd., Australia).

Collection of LV homogenates. Anesthetized rats were sacrificed by cervical dislocation. Parts of the LV obtained from rats were homogenized in cold phosphate buffer, containing ethylenediaminetetraacetic acid (EDTA). The supernatant obtained was stored at $-70{ }^{\circ} \mathrm{C}$ for biochemical assays. Other parts of these LVs were frozen at $-80^{\circ} \mathrm{C}$ and used for RNA extraction. Also, some LV samples were fixed in $10 \%$ formalin for histopathological evaluation.

Biochemical analysis in LV homogenates. IL-6 levels were measured using an ELISA Kit (Cat No. ELR-IL6-001) purchased from RayBio, MO, USA. Levels of TNF- $\alpha$ were measured using an ELISA kit (Cat no. ab46070) purchased from Abcam, Cambridge, MA, USA. Glutathione peroxidase (GPx) activities were measured using a commercial assay kit (Cat. No. 703102, Cayman Chemical, Ann Arbor, MI, USA).

Detection of Bax mRNAs by reverse transcriptasepolymerase chain reaction ( RT-PCR). Total RNAs were isolated from freshly dissected left ventricles of the rats, using the RNeasy Mini Kit (Qiagen Pty, Victoria, Australia). The RNA was reverse-transcribed for a single strand cDNA synthesis (Invitrogen) and amplified by PCR using primer pairs for Bax and b-actin derived from the published cDNA sequence as previously described (Eleawa et al., 2014). The PCR products were separated by $2 \%$ agarose gel 
electrophoresis and visualized by ethidium bromide, and gel images were scanned and quantified by densitometryusing the NIH image software.

Histopathological studies. Parts of the LV were rapidly fixed in $10 \%$ neutral buffered formalin, dehydrated in ascending concentrations of ethyl alcohol (70-100 \%) and then prepared using standard procedures for Hematoxylin and Eosin (H\&E) staining.

Statistical analysis. Statistical analyses were performed by using Graphpad prism statistical software package (version 6). Data were presented as means with their standard Deviation (mean $\pm S D)$. Normality and homogeneity of the data were confirmed before ANOVA, differences among the experimental groups were assessed by one-way ANOVA followed by Tukey's t test.

\section{RESULTS}

Induction of a combined MI and LVD animal model by CUS. We induced the disease in the model group of Wistar rats by daily exposure to CUS for 21 days that was shown by the ECG data analysis and basic histological staining (Fig. 1). An elevation of ST segment on the ECG compared to control group (Figs. 1A and 1B) was observed. LV tissue sections were examined by light microscopy after staining with hematoxylin and eosin (H\&E). Rats exposed to CUS (model group) showed a profound damage to LV tissues compared to normal tissue histology in the control group (Figs. 1C and 1D) as demonstrated by cardiac muscle degeneration with loss of myofibrils, wide areas of intramyofiber edema and haemorrhage.

\section{Quercetin inhibits CUS-induced changes in the ECG} reading. We confirmed the production of a rat model of CUS-induced MI and LVD (Fig. 1). We then investigated whether treatment with quercetin for 21 days, started at the same time rats were exposed to CUS, can block the occurrence of a heart attack. Compared to control groups that showed normal ECG reading (Figs. 2A and 2B) and the model group (Fig. 2C) that showed abnormal ECG, an elevation in the ST segment on the ECG, rats treated with quercetin maintained a normal ECG reading including a normal ST segment (Fig. 2D).

Quercetin inhibits CUS-induced hypertension. To test the hypothesis that chronic stress in this animal model can in-
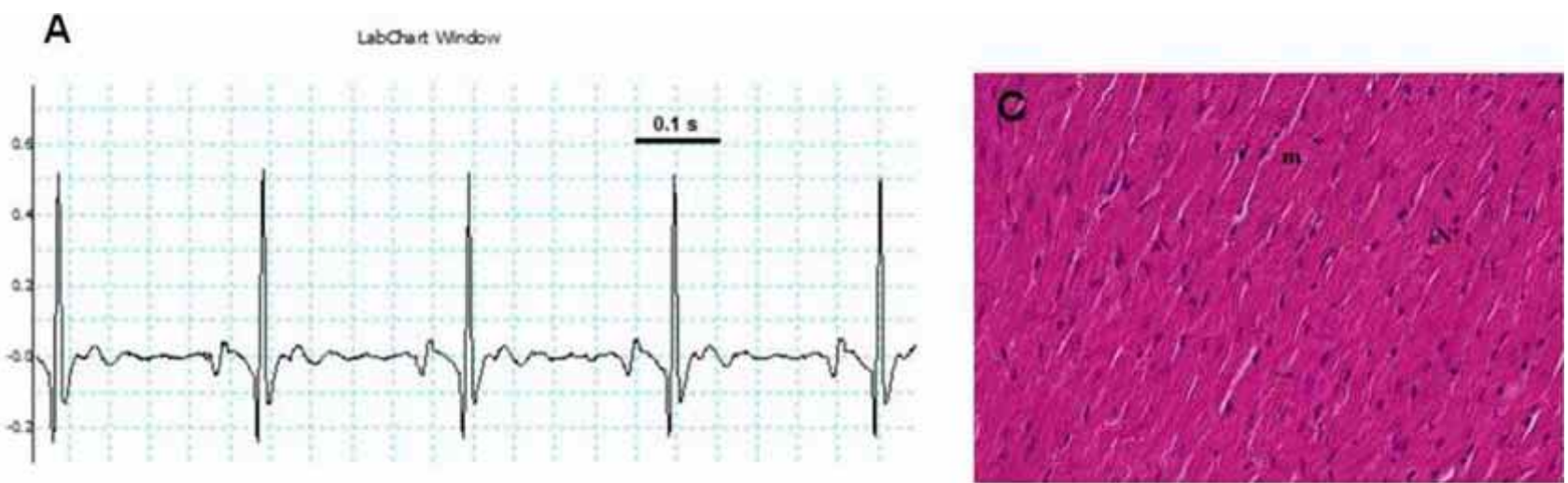

B
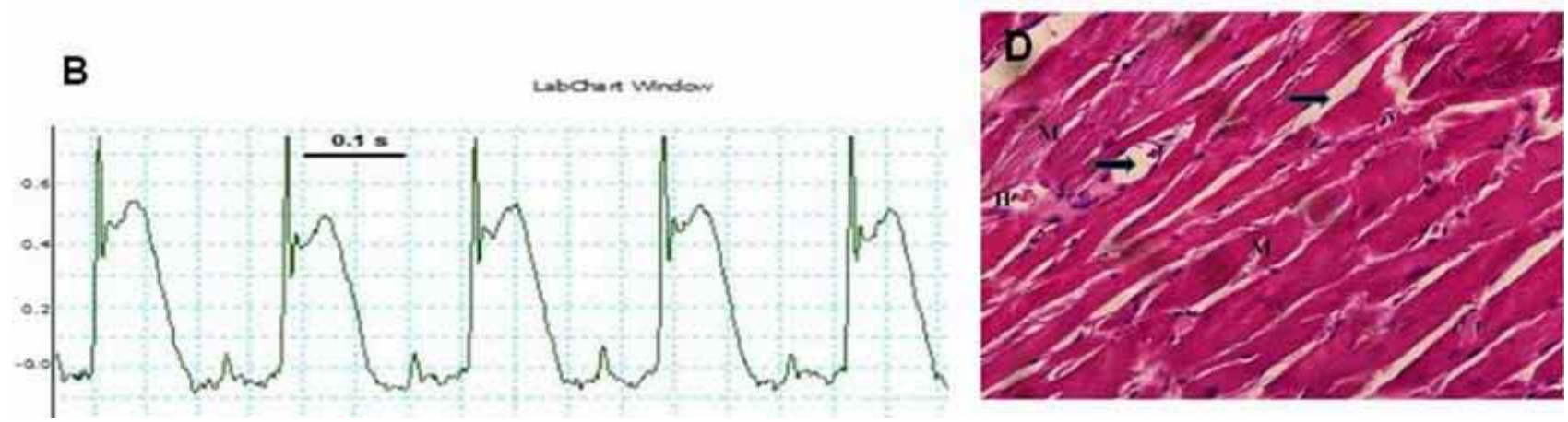

Fig. 1. Induction of MI and LVD in rats by CUS. Samples of ECG reading obtained from the control group of rats (A) compared to the model group of rats (B) exposed to CUS for 21 days. H\&E stained images (x400) of harvested tissues obtained from the LV after 3 weeks from control (C) and CUS (D) are visualized using light microscopy. Abbreviations: N, nucleous; m, myofibrils; H, haemorrhage. Note that arrows point to the intramyofiber edema. 

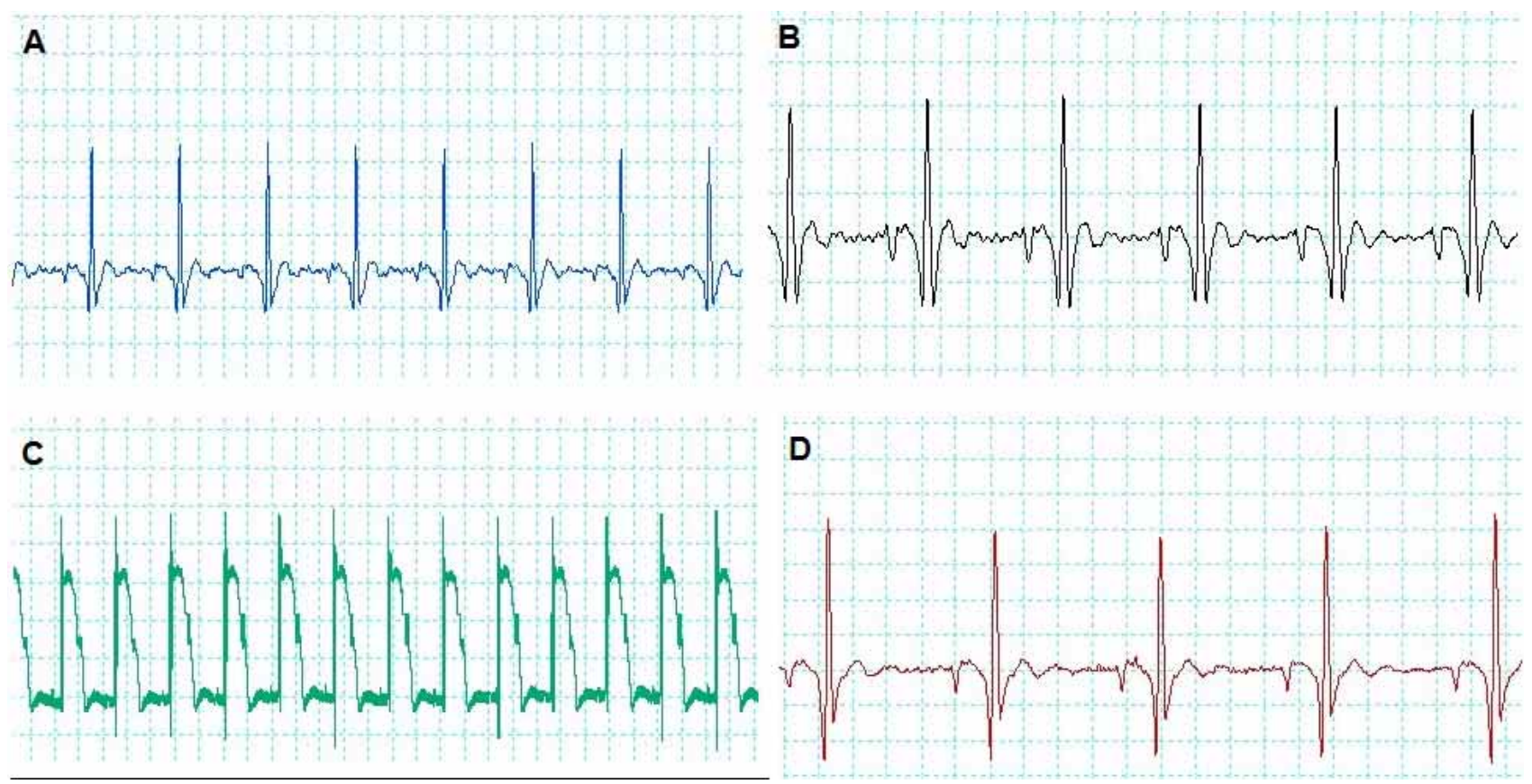

Fig. 2. Quercetin protects against CUS-induced MI. Samples of ECG trace recording obtained from all groups of rats; Control (A), Control + QUR (B), CUS (C), and CUS + QUR (D) groups after 21 days using PowerLab acquisition system and software (AD Instruments, Sydney, Australia).

Table I Blood pressure measurements for all the animal groups. Values are expressed as Mean \pm $\mathrm{SD}$ for 6 rats in each group. Analysis by one way ANOVA and Tukeys t-test. Values were considered significantly different at $\mathrm{P}<0.05$. a : Significant in comparison to Control group, b : Significant in comparison to Control + quercetin group, $\mathrm{c}$ :Significant in comparison to Chronic stress group.

\begin{tabular}{lccc}
\hline \multicolumn{1}{c}{ Animal groups } & SP $(\mathrm{mmHg})$ & DP $(\mathrm{mmHg})$ & MAP $(\mathrm{mmHg})$ \\
\hline Control & $110.0 \pm 6.8$ & $75.6 \pm 7.4$ & $88.3 \pm 5.6$ \\
Control + Quercetin & $112.2 \pm 7.8$ & $74.3 \pm 6.9$ & $86.6 \pm 6.2$ \\
Chronic stress & $176.8 \pm 11.3 \mathrm{a}^{\mathrm{b}}$ & $118.8 \pm 9.7^{\mathrm{ab}}$ & $138.4 \pm 8.6^{\mathrm{ab}}$ \\
Chronic stress + Quercetin & $121.6 \pm 7.4^{\mathrm{c}}$ & $78.5 \pm 5.6 \mathrm{c}$ & $91.6 \pm 5.7 \mathrm{c}$ \\
\hline
\end{tabular}

Abbreviations: SP, systolic pressure; DP, diastolic pressure; MAP, mean arterial pressure.

duce hypertension and whether quercetin is able to block these changes, we measured systolic (SP), diastolic (DP), and mean arterial (MAP) blood pressures in all the groups. Table 1 shows data on SP, DP, and MAP. Compared to control unstressed rat groups, CUS group showed a significant $(\mathrm{p}<0.05)$ increase in all blood pressure parameters. Compared to the stressed rat group, simultaneous quercetin treatment (CUS+QUR group) significantly ( $\mathrm{p}<0.05)$ inhibited the rise in blood pressure to levels comparable to control groups.

Quercetin inhibits CUS-induced augmentation of biomarkers of inflammation. Tissue inflammation is known to be involved in the pathology of heart disease including MI and LVD (Krishnamurthy et al., 2009). To test the hypothesis that quercetin can inhibit inflammatory biomarkers in LV tissue, we measured the levels of the proinflammatory cytokines TNF- $\alpha$ and IL-6 in LV homogenates. As shown in Fig. 3, CUS increased IL-6 levels by a threefold (Fig. 3A) and TNF- $\alpha$ by a five-fold (Fig. 3B) in the model group compared to control. Quercetin significantly $(p<0.05)$ inhibited TNF- $\alpha$ and IL-6 levels in the CUS+QUR group compared to CUS group. The reduction level was comparable to control but not comparable to Control+QUR group.

Quercetin inhibits CUS-induced upregulation of Bax gene and downregulation of GPx protein. We recently reported that CUS modulated both the survival and apoptotic proteins, Bcl-2 and caspase- 3 , and quercetin blocked the effect of CUS on these proteins (Bin-Jaliah, 2017). Here, 
we investigated the expression of the proapoptotic gene Bax in LV homogenates and assessed RNA messages using RTPCR. In addition, we assessed the level of the antioxidant protein, GPx in the same tissue homogenates. CUS augmented Bax (Fig. 4A) and ameliorated GPx (Fig. 4B), and quercetin blocked CUS effects.
A

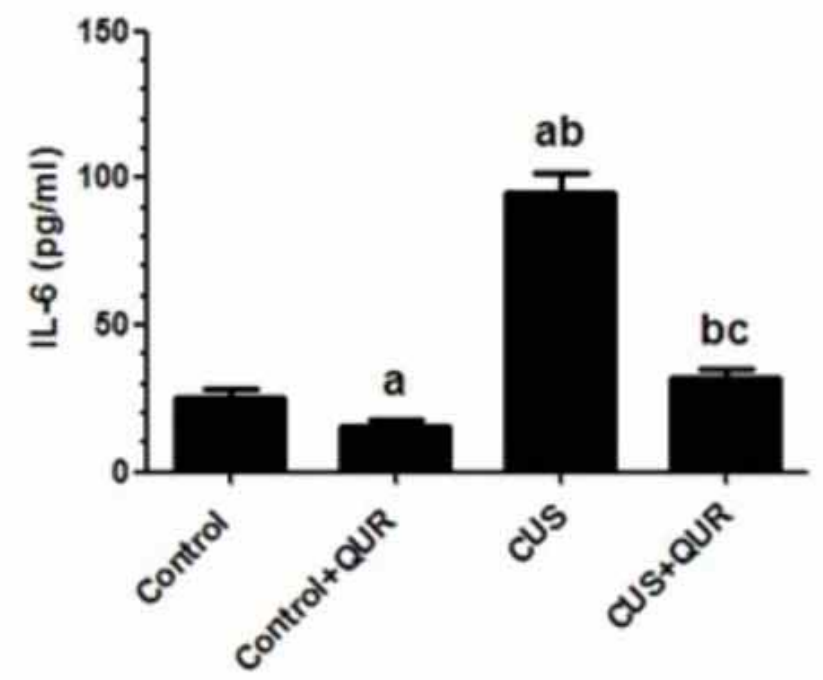

B

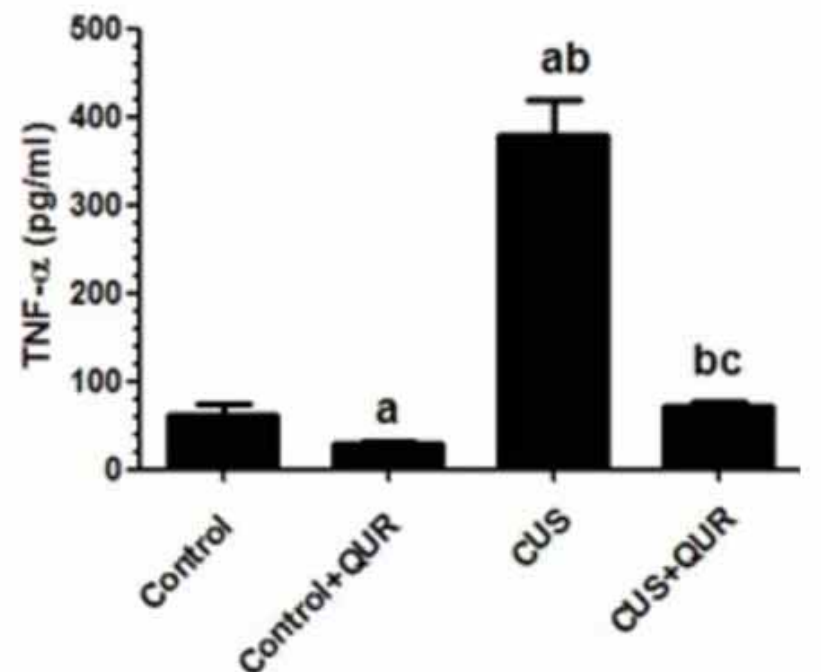

Fig. 3. Quercetin inhibits CUS-induced augmentation of inflammatory biomarkers. LV tissue levels of IL-6 (A) and TNF- $\alpha$ (B) were measured 21 days after the start of CUS and quercetin treatments in 4 groups of rats; Control, Control + QUR, CUS, and CUS + QUR groups. Results represent the mean $( \pm S D) ; n=6$ for each group. Experiments were performed in triplicate. All shown $p$ values are significant $(\mathrm{P}<0.05)$. a:Significantly different to control group. b:Significantly different to Control+QUR. c:Significantly dif-ferent to CUS.

A
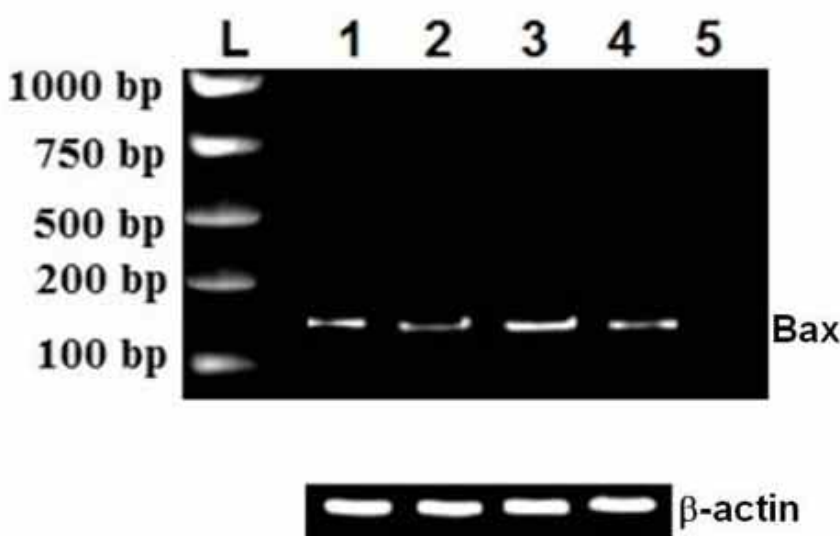

B

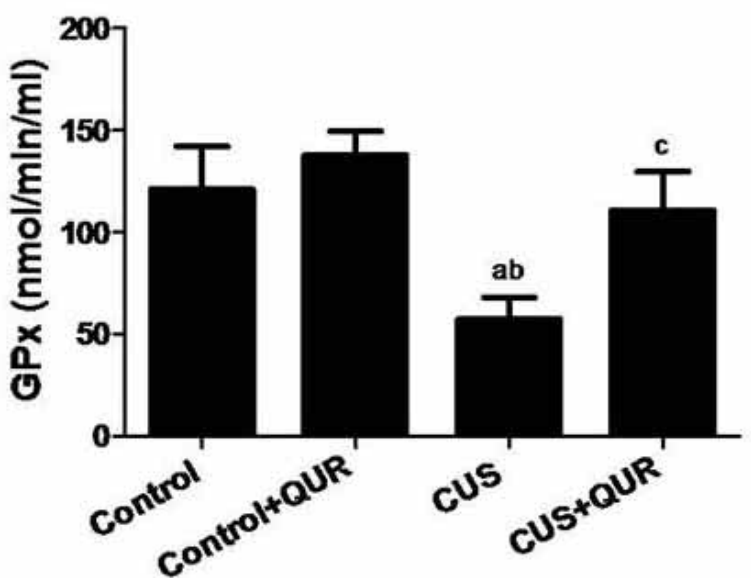

Fig. 4. Quercetin inhibits CUS-induced modulation of Bax gene and GPx enzyme. LV tissue levels of Bax (A) and GPx (B) were measured, using RT-PCR analysis for (A) and ELISA for (B ), 21 days after the start of CUS and quercetin treatments in 4 groups of rats; Control, Control + QUR, CUS, and CUS + QUR groups. cDNA samples (lane 1, control; lane 2, control+QUR; lane 3, CUS; lane 4, CUS+QUR; and lane 5 negative control) derived from LV tissue were amplified using primer pairs for Bax gene (produced a band of 143 $\mathrm{bp}$ in size) and the housekeeping gene, $\beta$-actin $(110 \mathrm{bp})$. Results for CPx represent the mean $( \pm \mathrm{SD})$; $n=6$ for each group. Experiments were performed in triplicate. All shown $\mathrm{p}$ values are significant $(\mathrm{P}<0.05)$. ${ }^{\mathrm{a}}$ :Significantly different to control group. ${ }^{\mathrm{b}}$ :Significantly different to Control+QUR. c:Significantly dif-ferent to CUS. 


\section{DISCUSSION}

The main objectives of our study were to develop an animal model of MI and LVD induced by CUS that mimics these heart diseases in humans caused by chronic stress. We then used this model to investigate whether the cardioprotective agent, quercetin can prevent MI. We also sought to further extend on our recent findings about the role of apoptosis in LVD to assess the activity of the proapoptotic gene, Bax in this model. Therefore, rats were exposed to CUS daily for 21 days in the presence and absence of quercetin. The principal findings in our study were that (i) CUS caused hypertension and showed abnormalities in both, the ECG reading and LV tissue histology; (ii) CUS augmented tissue inflammatory biomarkers and proapoptotic gene activity; and (iii) quercetin substantially inhibited all the pathophysiological abnormalities mentioned above. These conclusions are supported by the data indicating that CUS markedly increased SP, DP, MAP, IL-6, TNF-a levels, and Bax RNA messages, which were significantly inhibited by quercetin (Table 1 and Figs. 3 and 4). Furthermore, CUS induced MI as shown by an elevation in the ST segment on the ECG, and quercetin inhibited CUS-induced MI (Fig. 2). Therefore, our data is the first to report that CUS-induced MI in a rat animal model, and quercetin blocked the heart attack in this model.

Elevated levels of inflammatory biomarkers concomitant sometimes with the inhibition of the antioxidative stress are suggestive of active inflammatory diseases such as cardiovascular disease including stressinduced cardiac dysfunction (Black \& Garbutt, 2002). In addition, previous reports also mentioned a protective role for quercetin in inflammation, oxidative stress, and cardiovascular disease (Duarte et al.; Rogerio et al.). Therefore, our data that show an effective induction of the inflammatory biomarkers TNF- $\alpha$ and IL-6 (Fig. 3) and suppression of the antioxidant enzyme GPx (Figure 4B) caused by CUS, which were blocked by quercetin are in agreement with these studies.

We recently reported (Bin-Jaliah) that apoptosis is involved in the pathology of CUS-induced LVD because CUS augmented the apoptotic enzyme, caspase- 3 and inhibited the survival protein, Bcl-2 in LV homogenates. Since the proapoptotic Bax protein is located upstream of caspase- 3 and since Bax translocation (inhibited by Bcl-2 and antioxidants) into the mitochondria causes the release of cytochrome $\mathrm{c}$ that activates caspase-3 and hence apoptosis (Eldering et al., 2004), therefore we assessed the level of Bax RNA messages in rats exposed to CUS and CUS-treated with quercetin. Indeed, our data shown in Fig. 4, which point to the inhibition of GPx and induction of Bax messages by CUS further proof that the type of apoptosis we have in this animal model is the classical one, a caspase-induced apoptosis (Eldering et al.). It is in agreement with previous reports where mild type of CUS in rats induced the proapoptotic Bax protein in the myocardium(Dang et al., 2016), caused myocardial injury and increased cardiomyocyte apoptosis in cultured cells. Also, it is in agreement with the report that showed stress-induced overproduction of oxidative stress biomarkers caused apoptosis and enhanced levels of lipid peroxidation and peroxynitrite that damages DNA in heart tissues (Wang et al., 2013).

We believe our data demonstrates, by physiological, pathological, pharmacological, and molecular approaches, an animal model of CUS-induced MI and LVD, possibly via a caspase-induced cardiac cell death that was inhibited by quercetin.

\section{ACKNOWLEDGMENTS}

The support and input of Professors Bahjat Al-Ani and Mohamed A Haidara from the Departments of Physiology, College of Medicine, King Khalid University are highly appreciated by the author of this work. The author also would like to thank Mr. Mahmoud Al-Khateeb from the Departments of Physiology and Mr. Riyadh Al-Eissa from the Department of Biochemistry, College of Medicine, King Khalid University for their help in the experimental procedures.

BIN-JALIAH, I. La quercetina inhibe el infarto al miocardio inducido por estrés crónico en ratas. Int. J. Morphol., 35(4):1363-1369, 2017.

RESUMEN: Reportamos recientemente que el estrés crónico súbito (ECS) induce disfunción ventricular izquierda (DVI) en ratas, la que fue inhibida por la quercetina un agente cardioprotector. En base de estos hallazgos y debido a que la mayoría de los pacientes con infarto de miocardio (IM) pueden desarrollar DVI e insuficiencia cardíaca, se buscó producir un modelo animal de IM y DVI en ratas, utilizando este modelo para probar la hipótesis de que la quercetina puede prevenir la inducción potencial de IM por ECS. Las ratas fueron expuestas a ECS usando una variedad de factores de estrés de quercetina (50 mg / kg de peso corporal / día) durante 21 días. Se registró la presión sanguínea y el electrocardiograma (ECG) en todos los grupos de ratas junto con el examen de homogeneizados de tejido del ventrículo izquierdo (VI) y secciones para confirmar la producción del modelo animal. Asociamos los recientes hallazgos sobre el papel de la apoptosis en la patología de DVI y, finalmente, IM. Las mediciones de la presión arterial y la grabación de ECG confirmaron el desarrollo de hipertensión sistémica y del IM en el grupo modelo de ratas expuestas a ECS. Además, la tinción histológica confirmó que el daño del VI se produjo en el mismo grupo. Tambien se obervó un aumento del gen proapoptótico Bax y de los biomarcadores inflamatorios, TNF- $\alpha$ e IL-6. El trata- 
miento simultáneo con quercetina redujo la presión sanguínea y evitó sustancialmente el IM, bloqueando el aumento del segmento ST en el ECG. Por lo tanto, el IM inducido por ECS en ratas asociado con el aumento de los biomarcadores de lesión tisular, fueron impedidos por la quercetina, lo que concuerda con nuestros hallazgos recientes de un posible papel terapéutico de la quercetina en la disfunción cardíaca inducida por ECS.

PALABRAS CLAVE: Estrés crónico; Infarto de miocardio; ECG; Modelo de rata; Quercetina; Biomarcadores inflamatorios.

\section{REFERENCES}

Bin-Jaliah, I. Quercetin inhibits left ventricular dysfunction induced by chronic stress in rats. Int. J. Morphol., 35(2):654-60, 2017.

Black, P. H. \& Garbutt, L. D. Stress, inflammation and cardiovascular disease. J. Psychosom. Res., 52(1):1-23, 2002.

Burda, S. \& Oleszek, W. Antioxidant and antiradical activities of flavonoids. J. Agric. Food Chem., 49(6):2774-9, 2001.

Carnevali, L.; Mastorci, F.; Audero, E.; Graiani, G.; Rossi, S.; Macchi, E.; Callegari, S.; Bartolomucci, A.; Nalivaiko, E.; Quaini, F.; Gross, C. \& Sgoifo, A. Stress-induced susceptibility to sudden cardiac death in mice with altered serotonin homeostasis. PLoS One, 7(7):e41184, 2012.

Choi, Y. J.; Jeong, Y. J.; Lee, Y. J.; Kwon, H. M. \& Kang, Y. H. ()Epigallocatechin gallate and quercetin enhance survival signaling in response to oxidant-induced human endothelial apoptosis. J. Nutr., 135(4):707-13, 2005.

Dang, R.; Guo, Y.; Zhang, L.; Chen, L.; Yang, R. \& Jiang, P. Chronic stress and excessive glucocorticoid exposure both lead to altered Neuregulin-1/ ErbB signaling in rat myocardium. Steroids, 112:47-53, 2016.

Dong, M.; Giles, W. H.; Felitti, V. J.; Dube, S. R.; Williams, J. E.; Chapman, D. P. \& Anda, R. F. Insights into causal pathways for ischemic heart disease: adverse childhood experiences study. Circulation, 110(13):1761-6, 2004.

Duarte, J.; Pérez-Palencia, R.; Vargas, F.; Ocete, M. A.; Pérez-Vizcaino, F.; Zarzuelo, A. \& Tamargo, J. Antihypertensive effects of the flavonoid quercetin in spontaneously hypertensive rats. Br. J. Pharmacol., 133(1):117-24, 2001.

Eldering, E.; Mackus, W. J.; Derks, I. A.; Evers, L. M.; Beuling, E.; Teeling, P.; Lens, S. M.; van Oers, M. H. \& van Lier, R. A. Apoptosis via the B cell antigen receptor requires Bax translocation and involves mitochondrial depolarization, cytochrome C release, and caspase-9 activation. Eur. J. Immunol., 34(7):1950-60, 2004.

Eleawa, S. M.; Alkhateeb, M. A.; Alhashem, F. H.; Bin-Jaliah, I.; Sakr, H. F.; Elrefaey, H. M.; Elkarib, A. O.; Alessa, R. M.; Haidara, M. A.; Shatoor, A. S. \& Khalil, M. A. Resveratrol reverses cadmium chloride-induced testicular damage and subfertility by downregulating p53 and Bax and upregulating gonadotropins and Bcl-2 gene expression. J. Reprod. Dev., 60(2):115-27, 2014

Everson, S. A.; Goldberg, D. E.; Kaplan, G. A.; Cohen, R. D.; Pukkala, E.; Tuomilehto, J. \& Salonen, J. T. Hopelessness and risk of mortality and incidence of myocardial infarction and cancer. Psychosom. Med., 58(2):113-21, 1996

Harro, J.; Häidkind, R.; Harro, M.; Modiri, A. R.; Gillberg, P. G.; Pähkla, R.; Matto, V. \& Oreland, L. Chronic mild unpredictable stress after noradrenergic denervation: attenuation of behavioural and biochemical effects of DSP-4 treatment. Eur. Neuropsychopharmacol., 10(1):5-11, 1999.

Hubbard, G. P.; Wolffram, S.; Lovegrove, J. A. \& Gibbins, J. M. Ingestion of quercetin inhibits platelet aggregation and essential components of the collagen-stimulated platelet activation pathway in humans. J. Thromb. Haemost., 2(12):2138-45, 2004.
Kivimäki, M.; Virtanen, M.; Elovainio, M.; Kouvonen, A.; Väänänen, A. \& Vahtera, J. Work stress in the etiology of coronary heart disease--a metaanalysis. Scand. J. Work Environ. Health, 32(6):431-42, 2006.

Krishnamurthy, P.; Rajasingh, J.; Lambers, E.; Qin, G.; Losordo, D. W. \& Kishore, R. IL-10 inhibits inflammation and attenuates left ventricular remodeling after myocardial infarction via activation of STAT3 and suppression of HuR. Circ. Res., 104(2):e9-18, 2009.

Li, J.; Hansen, D.; Mortensen, P. B. \& Olsen, J. Myocardial infarction in parents who lost a child: a nationwide prospective cohort study in Denmark. Circulation, 106(13):1634-9, 2002.

Mateus, P. S.; Dias, C. C.; Betrencourt, N.; Adão, L.; Santos, L.; Sampaio, F.; Mateus, C.; Primo, J.; Simões, L.; Barros, H. \& Ribeiro, V. G. Left ventricular dysfunction after acute myocardial infarction--the impact of cardiovascular risk factors. Rev. Port. Cardiol., 24(5):727-34, 2005.

Mehta, P. K.; Wei, J. \& Wenger, N. K. Ischemic heart disease in women: a focus on risk factors. Trends Cardiovasc. Med., 25(2):140-51, 2015.

Nabel, E. G. \& Braunwald, E. A tale of coronary artery disease and myocardial infarction. N. Engl. J. Med., 366:54-63, 2012.

Park, C.; So, H. S.; Shin, C. H.; Baek, S. H.; Moon, B. S.; Shin, S. H.; Lee, H. S.; Lee, D. W. \& Park, R. Quercetin protects the hydrogen peroxide-induced apoptosis via inhibition of mitochondrial dysfunction in $\mathrm{H} 9 \mathrm{c} 2$ cardiomyoblast cells. Biochem. Pharmacol., 66(7):1287-95, 2003.

Pratt, L. A.; Ford, D. E.; Crum, R. M.; Armenian, H. K.; Gallo, J. J. \& Eaton, W. W. Depression, psychotropic medication, and risk of myocardial infarction. Prospective data from the Baltimore ECA follow-up. Circulation, 94(12):3123-9, 1996.

Rogerio, A. P.; Kanashiro, A.; Fontanari, C.; da Silva, E. V.; Lucisano-Valim, Y. M.; Soares, E. G. \& Faccioli, L. H. Anti-inflammatory activity of quercetin and isoquercitrin in experimental murine allergic asthma. Inflamm. Res., 56(10):402-8, 2007.

Roshanzamir, S. \& Showkathali, R. Takotsubo cardiomyopathy a short review. Curr. Cardiol. Rev., 9(3):191-6, 2013.

Rozanski, A.; Blumenthal, J. A. \& Kaplan, J. Impact of psychological factors on the pathogenesis of cardiovascular disease and implications for therapy. Circulation, 99(16):2192-217, 1999.

Rozanski, A.; Blumenthal, J. A.; Davidson, K. W.; Saab, P. G. \& Kubzansky, L. The epidemiology, pathophysiology, and management of psychosocial risk factors in cardiac practice: the emerging field of behavioral cardiology. J. Am. Coll. Cardiol., 45(5):637-51, 2005.

Task Force on the management of ST-segment elevation acute myocardial infarction of the European Society of Cardiology (ESC); Steg, P. G.; James, S. K.; Atar, D.; Badano, L. P.; Blömstrom-Lundqvist, C.; Borger, M. A.; Di Mario, C.; Dickstein, K.; Ducrocq, G.; Fernandez-Aviles, F.; Gershlick, A. H.; Giannuzzi, P.; Halvorsen, S.; Huber, K.; Juni, P.; Kastrati, A.; Knuuti, J.; Lenzen, M. J.; Mahaffey, K. W.; Valgimigli, M.; van 't Hof, A.; Widimsky, P. \& Zahger, D. ESC Guidelines for the management of acute myocardial infarction in patients presenting with ST-segment elevation. Eur. Heart J., 33(20):2569-619, 2012.

Valensi, P.; Lorgis, L. \& Cottin, Y. Prevalence, incidence, predictive factors and prognosis of silent myocardial infarction: a review of the literature. Arch. Cardiovasc. Dis., 104(3):178-88, 2011.

Wang, Y.; Liu, X.; Zhang, D.; Chen, J.; Liu, S. \& Berk, M. The effects of apoptosis vulnerability markers on the myocardium in depression after myocardial infarction. B. M. C. Med., 11:32, 2013.

Corresponding author:

Dr. Ismaeel Bin-Jaliah

Department of Physiology

College of Medicine, King Khalid University

P.O. Box 641

Abha, 61421

SAUDI ARABIA

Received: 04-07-2017

Accepted: 13-09-2017

Email: isbinjaliah@kku.edu.sa 